\title{
The Phonology of Anglicisms in French, German and Czech: A Contrastive Approach
}

\author{
Tomáš Duběda \\ Associate Professor of Romance Linguistics, Faculty of Arts, Charles \\ University, Prague, Czech Republic \\ dubeda@ff.cuni.cz
}

\begin{abstract}
In this article, I analyse the phonological adaptation of Anglicisms in three languages (French, German and Czech) from a contrastive perspective. The classification of standard phonological forms, based on a system of eight adaptation principles, aims at capturing the degree of phonological permeability/resistance for each of the languages. Phonological approximation (the substitution of foreign phonemes with native ones) seems to be the fundamental principle in all three languages analysed. The spelling pronunciation principle is observed predominantly in French; phonological import occurs only in German. Globally, phonological resistance increases in the following order: German - Czech - French.
\end{abstract}

\section{Keywords}

phonological typology - phonological adaptation - loanwords - Anglicisms French - German - Czech

\section{Introduction}

The way in which borrowings are adopted may be studied from several perspectives, namely semantic, formal (phonological, morphological and syntactic) and extralinguistic (social and ideological). On the phonological level, a specific discipline called "Loanword Phonology" (Calabrese and Wetzels, 2009; Kang, 2011) models this process as a "repair" of an "offending input" with respect to native phonology. This process may be incomplete and result in 
the formal markedness of the borrowed phonological form (Vance, 2008). The higher the degree of phonological foreignness, the more the word is likely to be felt as a foreignism or as an instance of code-mixing. Furthermore, loanwords may exhibit greater phonological variability than native words (Retman, 1978), and the way in which they are pronounced may reveal information about the social status of the speaker (e.g., their level of education or knowledge of foreign languages).

From a sociolinguistic point of view, the concept of phonological "repair" is a simplified construct that, in reality, does not correspond to an instantaneous action performed by an ideal language user, but rather to a socially underpinned negotiation between competing principles within the target phonological system (Molęda, 2011; Duběda et al., 2014). Moreover, the phonology of loanwords is affected by extragrammatical factors and two of these factors are of particular relevance here. First, despite the standard view of phonology as a system independent of orthography, it has been demonstrated that loanwords are particularly exposed to the influence of spelling, as they are - more than native words - transmitted and learned in writing (Smith, 2006; Friesner, 2009; Escudero and Wanrooij, 2010; Molęda, 2011). Second, the adaptation of words borrowed from a particular language is at least partly conditioned by the status of this language and the knowledge of this language in the target population (Kang, 2011).

English is presently the most productive source of loanwords in many European languages, and indisputably the most important language of international communication. Being itself strongly hybridised, it became "by far the world's biggest lexical exporter" in the $20^{\text {th }}$ century (Görlach, 2001: 353). Anglicisms thus form a vast lexical stratum in many languages, including the three languages examined in this article. The phonology of Anglicisms can be seen as a peripheral component of native phonology that is associated, through a system of adaptation processes, with English phonology. In the present article, drawing on a previously published typological sketch (Duběda, 2016b), I describe these processes on a contrastive basis, comparing a representative sample of original phonological forms with their adapted counterparts in French, German and Czech. I go beyond a single-language perspective and make a contribution to the phonological typology of loanwords, a domain which to date has received only limited scholarly attention (Filipović, 1982; Görlach, 2001; Molęda, 2011)

After providing a general overview of the adaptation principles (Section 2), I briefly discuss the literature for each of the languages under investigation (Section 3). In Section 4 I advance the working hypotheses and in Section 5 
I present the lexical sample that I used for the analysis. In Section 6, I examine the relative weight of the individual adaptation principles, and in Section 7 , I describe the rules of phonological approximation. Finally, in Section 8 I give a summary of the results of the study and some general conclusions.

\section{Adaptation Principles}

The classification of adaptation processes is based on a set of eight languageindependent adaptation principles, proposed in Duběda et al. (2014). These principles, described in the literature under various names and with a varying degree of overlap, correspond to the different systemic forces that underlie phonological "repair".

1) Phonological approximation (substitution of original phonemes with perceptually related phonemes of the target language, phonotactic normalisation, prosodic normalisation). For example, fan club /'fænklıb/ is adapted in French as /fanklœb/ (the phonemes /f, n, k, l, $\mathrm{b} /$ are rendered by perceptually very similar target-language pho-

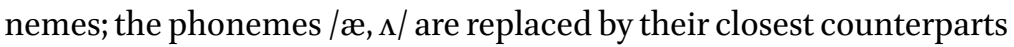
/a, œ/; stress is shifted to the final syllable). This principle is considered the most straightforward way of nativisation (Romportl, 1978; Kang, 2011). Metaphorically, it can be described as "looking at the foreign word through the eyes of native phonology".

2) Spelling pronunciation (conversion of the written form into the phonological form by virtue of the target-language conventions). For example, laser /'leiza/ is adapted in French as /lazes/ (and not */lezœu/, as it would be the case if phonological approximation were applied). As I pointed out in Section 1, spelling is a possible source of phonological change in the case of loanwords.

3) Original pronunciation (more or less successful imitation of the original pronunciation of the word).

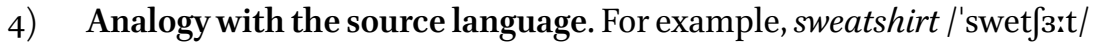
is often rendered in French as /switfœut/, by analogy with words where the digraph ea is realised as /i: / read, meat, deal).

5) Analogy with the target language. For example, engineering /endzi'nıərı// is often adapted in Czech as /inzenirrıkk/, by analogy with the word inženýr/mzenir/. This French borrowing entered the Czech lexicon well before the English word engineering, which is itself a Gallicism. This category also includes cases of folk etymology. 
6) Pronunciation influenced by a third language. For example, the Polish politician's name Donald Tusk is sometimes mistakenly converted in Czech to /task/ instead of /tusk/, by analogy with English grapheme-phoneme conversion rules.

7) Pronunciation influenced by universals. For example, the prevailing adaptation of the French word tartelette /tast(ə)let/ in Czech is tartaletka /tartaletka/, where the presence of /a/ in the second syllable may be explained as vowel harmony.

8) Unclearly motivated pronunciation. For example, the surname Mulder /'msldə/ is rendered, for no obvious reason, as /ma:ldr/ in the Czech version of the $X$-Files, although the English vowel $/ \Lambda /$ is normally adapted as a short $/ \mathrm{a} /$.

Principles 1-3 can be considered primary because they are characterised by a direct link of the target phonological form to the source phonology or spelling, and each of these principles affects the pronunciation of whole words as opposed to individual phonemes (e.g., the French adaptations /fanklob/ and /lazes/ cited above, which are based entirely on phonological approximation and spelling pronunciation, respectively). The same set of primary adaptation principles, though with different labels, is used by Kučera and Zeman (1998). The secondary principles $4-8$ have no direct link to the original pronunciation or spelling of the borrowed item. They do not affect the whole word, but only parts of it: in the examples 4-8 above, the impact of the secondary principles is limited to a few phonemes per word, the rest of the word being adapted according to principle 1 .

Two or more principles may combine within the same word: for example, in the French version of boy-scout /bojskut/, the first diphthong is adapted according to principle 1 and the second according to principle 2. Moreover, different principles may account for parallelly attested pronunciations: in French, the word pipeline is either /piplin/, or /pajplajn/ (principle 2 or 1). The effect of principle 3 may range from a discreet trace of non-native pronunciation to a genuine imitation of the foreign phonetic form.

The three primary principles may be structured along an axis which expresses the degree of phonological permeability/resistance (Duběda, 2016b):

Permeable

Original pronunciation
Resistant

Spelling pronunciation

FIGURE 1 Permeability/resistance scale 


\section{The Adaptation of Anglicisms in French, German and Czech}

It is likely that all the principles mentioned are attested in each of the studied languages, though to a different degree. The distribution of these principles is symptomatic of the way in which a given language treats foreign phonological input and can therefore be used as a typological criterion. This section contains concise phonological description of the three languages and information on previous studies on the phonological adaptation of Anglicisms (including lexicographic sources). I use IPA-based phonological transcription, leaving out features predictable from the context (e.g., stress in French and Czech, consonant syllabicity in English, German and Czech, and vowel length in French).

\subsection{French}

French is a Gallo-Romance language whose standard European variety has 11

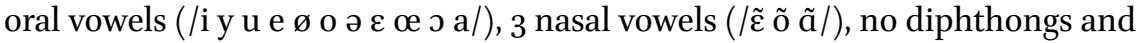
19 consonants (/p b t d k g m n n y f v s z 3 в j l/; cf. Léon, 2011; Fougeron and Smith, 1999). One phoneme $(/ \mathrm{g} /)$ is of foreign origin, supplied mainly by English loanwords (e.g., bowling /bulin/, shopping /Jjpin/; cf. Walter, 1983). Primary stress is on the last full syllable (final syllables containing an /ə/ are not considered full); secondary stress is word-initial.

The phonology of French Anglicisms has, surprisingly perhaps, not received a great deal of coverage in the scientific literature (cf. the bibliography collected by Görlach, 2002). Most works are devoted to phonology in general, with little reference to Anglicisms (Walter, 1976), to Anglicisms with little reference to phonology (Aitokhuehi, 1996; Seridj, 2013), or to practical issues related to the pronunciation of Anglicisms (Trescases, 1987). Retman (1978) and DaboDenegri (1991) are particularly relevant for the present study. Both authors adopt a similar descriptive approach, giving a fairly complete set of attested phonemic counterparts for each English phoneme. Although their analysis does not provide a clear separation of adaptation principles or a sufficiently detailed account of the influence of cross-language analogies, it does indicate that the prevailing principles are phonological approximation and spelling pronunciation. Original pronunciation does not seem to be a probable alternative for current loanwords. Warnant's pronunciation dictionary (1987) states for proper names of foreign origin that a full imitation of original pronunciation is nowadays perceived as snobbish, and it seems reasonable to assume that this applies a fortiori to borrowings.

All major dictionaries (e.g., Warnant, 1987; Le Petit Robert, 2012; Le grand Larousse illustré, 2017) give transcriptions based on French phonemes only (including / $/ \mathrm{y} /$ ); standard descriptions of French phonology (Tranel, 1987; 
Léon, 1992; Fougeron and Smith, 1999) have a similar approach. For proper names, Warnant (1987) accepts two more foreign phonemes $(/ \theta /$ and $/ x /)$, of

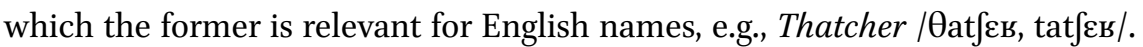
Apart from some exceptions (grill > gril; elf $>$ elfe; packet-boat > paquebot), Anglicisms mostly retain their original spelling.

\subsection{German}

German is a West Germanic language with 16 monophthongs (/i: y: u: I Y $\mho$ e: ø:

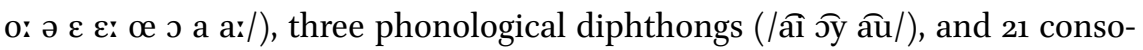
nants (/p b td kg m n yfvs z 3 Ç x h r jl/; cf. Mangold, 2005). The /r/ phoneme undergoes vocalisation in some contexts (e.g., besser /'besr/ ['bese] 'better'), and yields phonetic diphthongs postvocalically (e.g., Ohr /'orr/ ['ôe] 'ear'). For practical purposes, I keep the vocalic symbol in such positions. Literature on German phonology (Kohler, 1999) mostly acknowledges full phonemic status to only one phoneme of foreign origin (/3/ as in Garage /ga'ra:zo/), while lexicographic works adopt a more open stance (see below). Stress in German is free; in native words, it is usually placed on the first syllable of the root.

The phonology of Anglicisms in German has been studied from several perspectives. Fink (1980) presents an empirical investigation of a sample of Anglicisms (pronounced by 184 respondents) mostly from the second half of the $20^{\text {th }}$ century. Apart from phonological approximation and spelling pronunciation, he identifies a strong tendency to imitate the original English phonetic form, especially among young respondents. Muhvić-Dimanovski (1982) puts forward the same three primary principles, with phonological approximation being presented as the strongest. Busse (2005) analyses the transcription of Anglicisms in dictionaries and describes the tendencies underlying the adaptation of individual phonemes. He shows that the import of foreign sounds is accepted as a part of standard pronunciation, as the transcriptions found in the dictionaries include German, English and mixed phonological forms. Lange (2015) focuses on the pronunciation of English proper names.

The Duden-Aussprachewörterbuch (Mangold, 2005) includes in the list of

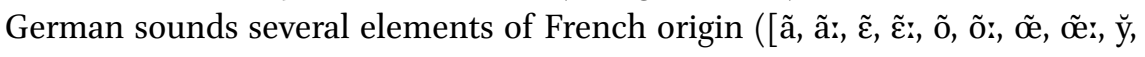
3]) and one of English origin ([d]]). A separate list of sounds to be used in "foreign pronunciation" includes all symbols used in British English except for those which also occur in German. The Duden - Deutsches Universalwörterbuch (2007) has a comparable approach, but contains a shorter list of English sounds to be used in foreign pronunciation $([\mathrm{a}, \mathfrak{x}, \Lambda, \partial, \theta, \mathrm{w}])$. While the DudenAussprachewörterbuch gives mostly "germanised" (eingedeutscht, i.e., applying the principle of phonological approximation) pronunciation for borrowings, the original pronunciation is listed for most proper names. The Duden - Deutsches 
Universalwörterbuch, despite its wider target group, goes even further, and acknowledges original English pronunciation in a significant number of borrowings, either as the only variant (Franchising /'fræntfarzı/, Playback/'plerbæk/), or as an alternative to nativised pronunciation (Slogan /'slo:gn, 'sloogən/). An informal observation of German-speaking media provides further evidence of the tolerance of German to phonological import. Orthographic adaptation of Anglicisms is not frequent $(\operatorname{dog}>$ Dogge; mop $>$ Mopp $)$.

\subsection{Czech}

Czech is a Western Slavonic language with approximately 11 million speakers. It is closely related to Slovak and is the only official language of the Czech Republic as well as one of the official languages of the European Union. It has highly inflected morphology and relatively free word order. Most of its lexicon is of Slavonic origin, with peripheral layers of words of German, Latin, Greek, and, more recently, French and English origin. The Czech phonemic system comprises five short vowels (/ $\varepsilon$ a o u/), five long vowels (/i: $\varepsilon$ : a: o: u:/), three diphthongs (/रิ au oû/) and 25 consonants (/p t c k b d $\mathrm{g} f \mathrm{~s} \int \mathrm{x} \mathrm{v} \mathrm{z} 3 \mathrm{~h}$ ts $\mathrm{f} \mathrm{m} \mathrm{n}$ $\mathrm{pl} \mathrm{j} \mathrm{r} \mathrm{r} /$; cf. Dankovičová, 1999). Several of these phonemes are of foreign origin, but are nowadays well integrated: /f/ as in film 'film', /g/ as in garáż 'garage', /d]/ as in jazz 'jazz', /o:/ as in kód 'code', /âu/ as in auto 'car', / $\widehat{\varepsilon u} /$ as in euro 'Euro'. Phonetically speaking, none of these elements is entirely foreign, as they exist either as contextual variants of native phonemes (krev ['kref] 'blood', kdo ['gdo] 'who', léčba ['le:dzba] 'treatment'), or can be easily derived from them $([\mathrm{o}:]<[\mathrm{o}],[\widehat{\mathrm{au}}]<[\mathrm{a}+\mathrm{u}],[\widehat{\varepsilon u}]<[\varepsilon+\mathrm{u}]$. Stress is placed on word-initial syllables.

As far as the adaptation of Anglicisms is concerned, although several works are based on the observation of actual language use, the literature is predominantly prescriptive (Romportl, 1978; Hůrková, 1995). Descriptive approaches include Kučera and Zeman's analysis of proper names of English origin (Kučera and Zeman, 1998) and a recent empirical investigation into the pronunciation of loanwords (Duběda, 2016a), in which 300 native speakers of Czech participated. A phonological analysis of Anglicisms in Czech, based on dictionary data, is proposed in Bičan et al. (2020). All sources indicate that Czech is a language which favours phonological approximation and, to a lesser extent, spelling pronunciation. Original pronunciation is considered unusual in everyday communication (Hůrková, 1995), but does occur in proper names and citations used in intellectual contexts (ibid.), and, perhaps, in informal communication on topics such as pop culture or modern life.

Major dictionaries (Slovník spisovného jazyka českého; Slovník současné češtiny; Nový akademický slovník cizich slov) are unanimous in transcribing 
borrowings with Czech phonemes only. Czech spelling is strongly phonologi$\mathrm{cal}$, and language users normally expect a regular mapping between the spoken and the written form. This expectation is mostly not satisfied with loanwords that have retained their original spelling. As a consequence, many loanwords, including Anglicisms, have been orthographically adapted (sweater $>$ svetr, tramway > tramvaj) or have alternative spelling (jazz> jazz/džez, handicap > handicap/hendikep). Well integrated words are more likely to undergo adaptation than newer and less frequent words (Romportl, 1978).

The goal of my investigation is to compare the degree of phonological permeability/resistance with respect to Anglicisms in French (FR), German (DE) and Czech (CS). Each of these languages represents one of the three major branches of Indo-European languages spoken in Europe (Romance, Germanic and Slavonic). Following the discussion presented in the previous section, I intend to quantitatively verify the following hypotheses:

1) Phonological approximation is more straightforward in German than in the other two languages, given the typological proximity between German and English. It is likely that the replacement of foreign phonological forms by domestic forms requires less phonetic, phonological and phonotactic manipulation when the languages are phonologically similar;

2) The principle of phonological approximation prevails in all three languages and can be considered the default principle of loanword adaptation in each of them. Irrespective of the degree of manipulation required for phonological approximation, this principle is considered dominant in the specialist literature;

3) French favours spelling pronunciation more than the other two languages. Although the spelling principle is observed in all three target languages, it appears - from an informal inspection of adapted forms - that spelling-based adaptation is more common in French than in the other studied languages;

4) German is more tolerant towards original pronunciation than the other two languages. From informal observation of language use and from the analysis of lexicographic sources it seems that German is more permeable to phonological import than French or Czech. 
The study does not target conscious attitudes of individual speakers or groups of speakers; its focus is on the phonological systems relevant for loanwords. More specifically, it reflects one specific pronunciation register: standard speech.

The analysed sample is based on the wordlist published in the Dictionary of European Anglicisms (Görlach, 2001), which contains approximately 3,500 entries. Roughly a quarter of these entries are provided with more detailed information on the word's history, as well as a diagram of the languages where it is attested. I used these $85^{2}$ entries, all of them corresponding to frequent and widely attested Anglicisms, as the starting point of the analysis.

The target phonological forms were retrieved from the following authoritative dictionaries:

- FR: Dictionnaire de la prononciation française dans sa norme actuelle (Warnant, 1987) [A Normative Dictionary of Contemporary French Pronunciation].

- DE:Duden. Das Aussprachewörterbuch (Mangold, 2005) [Duden. The Pronunciation Dictionary].

- CS: Nový akademický slovník cizích slov (2014) [New Academic Dictionary of Loanwords].

The 1987 edition of Warnant's dictionary is the most up-to-date French pronunciation dictionary. I checked its appropriateness by comparing the retrieved phonological forms informally with a recent edition of the Petit Robert (2012) and found out that the transcriptions given in Warnant are not dated and are sufficiently reliable. In the preface, the author states that the data reflect both "scientific knowledge in the domain of phonetics and linguistics" and a "long and careful observation of facts" (Warnant, 1987: xiii). The dictionary, though published in Belgium, is based on the standard pronunciation of the Paris region (Ibid.: $\mathrm{xx}$ ) and, more specifically, on the pronunciation of "educated people" (Ibid.: xxi).

For German, the Duden Aussprachewörterbuch is a modern and widely acknowledged work, containing "standard pronunciation[s]" and "reflecting the development of the language" (Mangold, 2005:5). The authors explicitly state that they focus specifically on the "germanised" way of pronunciation, while acknowledging that "foreign-language" pronunciation is an option, especially for proper names (Ibid.: 5). However, as I pointed out above, this position is not 
shared by the editors of all German dictionaries. For this reason, I also consulted the Duden - Universalwörterbuch (2007), which shows a much more open attitude in this respect than the Aussprachewörterbuch. I did not record the exact phonetic treatment of the entries in the Universalwörterbuch, but marked only those words for which the dictionary suggests non-adapted English pronunciation. This approach provides a more realistic view of the phenomena studied.

For Czech, the only available pronunciation dictionary (Romportl, 1978) did not meet my needs, as it is dated and does not reflect many recent Anglicisms that entered the language after the fall of the Iron Curtain in 1989 (Štěpánová, 2013). Therefore, I decided to use the Nový akademický slovník cizich slov, a modern comprehensive dictionary of loanwords. With regard to the choice of pronunciation forms, the authors rely on the rules and principles defined in Romportl (1978), complemented by "systematic research into trends of standard pronunciation" (NASCS, 2014: 8). The suggested transcriptions are based on the "usage of speakers of standard Czech [...] provided that the word is part of their active lexicon" (Ibid.: 8).

The search returned 382 entries for French, 690 for German, and 518 for Czech. Out of the 852 initial entries, 245 were attested in all three dictionaries, 319 in two of them, and 217 in one of them. 71 entries were not attested in any of the three dictionaries. These numbers reflect each language's propensity for Anglicisms, as well as the size and the age of the dictionary used.

Next, each entry attested in at least one target language was provided with English pronunciation obtained from the Cambridge English Pronouncing Dictionary (Jones et al., 2011). Only British pronunciation forms were recorded, but differences in American pronunciation were considered in the analysis (see below). The transcriptions collected for English, French and German were IPA-based. The Nový akademický slovník cizích slov gives pronunciation in simplified Czech phonetic transcription, and only in cases where it cannot be easily derived from spelling. I therefore converted the transcriptions to IPA, and added missing transcriptions. In French, I replaced the symbols

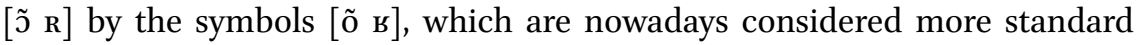
(Fougeron and Smith, 1999). In German and Czech, I provided diphthongs with a ligature ([âu, ou, ऽy, œิe ] etc.) to distinguish them from two-syllable vowel sequences. Details that have no phonological relevance were left out (see Section 3).

The phonological forms were then classified according to the primary principle that underlies their adaptation. The labels used are summarised in Table 1. 
TABLE 1 Labels used for the classification of entries according to primary adaptation principles

\begin{tabular}{|c|c|c|}
\hline APPROX & phonological approximation & FR feed-back /fidbak/ \\
\hline SPELL & spelling pronunciation & FR label /label/ \\
\hline ORIG & original pronunciation & $\begin{array}{l}\text { DE Challenger } \\
\text { /'tfælindza/ }\end{array}$ \\
\hline APPROX $=S P E L L$ & $\begin{array}{l}\text { phonological form that can be } \\
\text { explained simultaneously by } \\
\text { phonological approximation } \\
\text { and spelling pronunciation }\end{array}$ & CS drift /drift/ \\
\hline $\begin{array}{l}\text { APPROX+SPELL } \\
\text { APPROX+ORIG }\end{array}$ & $\begin{array}{l}\text { combination of two principles } \\
\text { within the same entry }\end{array}$ & $\begin{array}{l}\text { FR boy-scout /bojskut/ } \\
\text { DE Big Brother /'bik } \\
\text { 'braðe/ }\end{array}$ \\
\hline APPROX/SPELL & two competing variants & $\begin{array}{l}\text { FR pipeline /piplin, } \\
\text { pajplajn/ }\end{array}$ \\
\hline APPROX/ORIG & & $\begin{array}{l}\text { DE Display /dis'ple:, } \\
\text { dis'pleı/ }\end{array}$ \\
\hline
\end{tabular}

Each entry received one label describing the primary adaptation principle(s). Where applicable, I also marked secondary adaptation principles, using the labels ANAL for various kinds of analogies (DE: Cherrybrandy /'tferi'brendi, 'feri'brendi/, where the latter pronunciation form is probably the result of contamination by the word Sherry), and the label ANOM for cases that deviate from normal adaptation processes (FR: dispatcher / dispatfœь, dispafєь/, where the latter variant exhibits an unusual adaptation $|\mathrm{t}|>|\delta|$, not explainable by spelling). The examples in Table 2 illustrate the structure and the annotation of the sample.

TABLE 2 Annotation examples

Source form Target forms

$\begin{array}{lll}\text { feed-back } & \text { FRfeedback/fidbak/ } & \text { APPR } \\ \text { /'fi:dbæk/ } & \text { DE Feedback/'fittbek/ } & \text { APPR } \\ & \text { CS feedback/fi:dbek/ } & \text { APPR } \\ \text { champion } & \text { FR champion/fãpjõ/ } & \text { SPELL } \\ \text { /'tfæmpion/ } & \text { DE Champion/'tfempion/ } & \text { APPR } \\ & \text { CS šampion /famprjon/ } & \text { APPR+SPELL, ANAL (possibly } \\ & & \text { influence of French) }\end{array}$

Adaptation principles

JOURNAL OF LANGUAGE CONTACT 13 (2020) 327-3550 oaded from Brill.com04/26/2023 02:11:50PM 
TABLE 2 Annotation examples (cont.)

\section{Source form Target forms $\quad$ Adaptation principles}

$\begin{array}{lll}\text { star /'sta:/ } & \text { FR star /stab/ } & \text { APPR=SPELL } \\ & \text { DE Star /'stâe, 'ftâe/ } & \text { APPR/SPELL } \\ \text { CS star /sta:r/ } & \text { APPR }\end{array}$

It is obvious that the phonological forms listed in dictionaries reflect only part of the phonological reality, as borrowings tend to be phonologically more variable than native words (Retman, 1978; Duběda, 2016a). However, we can reasonably argue that the forms captured by dictionaries are not virtual but correspond to at least one representative pronunciation style - the style used by educated people in formal situations - and reflect typical processes of loanword adaptation. For this reason, they are a sufficiently reliable source for the purposes of a cross-linguistic study whose primary goal is not to describe sociolinguistic variability, but to compare phonological systems. Indeed, the use of standard pronunciation is a common approach in phonological typology (Maddieson, 1984) and often the only possible approach for practical reasons.

\section{The Relative Weight of the Adaptation Principles}

The data confirm the prominence of phonological approximation (APPROX). As we see in the charts, phonological approximation is clearly the most common principle in all three languages, accounting for more than a third of the entries in French and for almost two thirds in German and Czech (40\%, 65\% and $59 \%$, respectively). Hypothesis 2 is therefore confirmed. Figure 2 shows
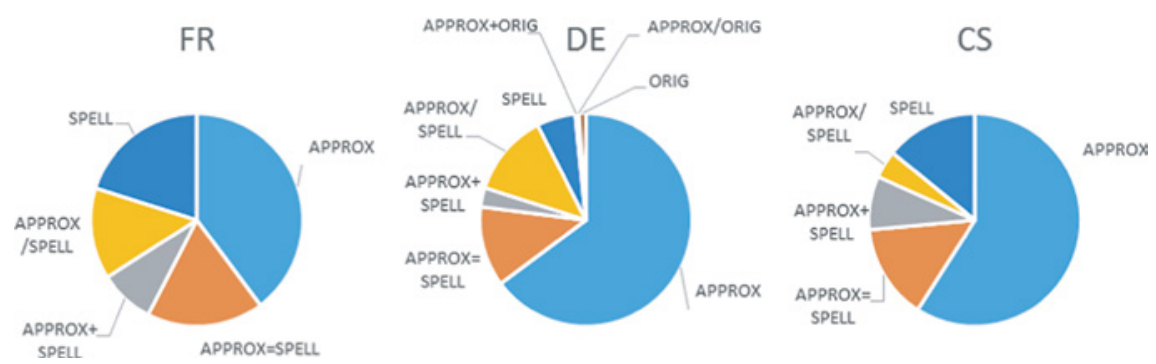

FIGURE 2 Relative weight of the adaptation principles in the sample. Total numbers of lexical units analysed: FR: $\mathrm{N}=382 ; \mathrm{DE}: \mathrm{N}=690 ; \mathrm{CS}: \mathrm{N}=518$ 
the relative weight of all three primary adaptation principles, as found in the sample. For the labels, cf. Table 1.

Spelling pronunciation in its pure form (SPELL) is active in $20 \%$ of the French entries, $14 \%$ of the Czech entries, and $4 \%$ of the German entries. The remaining part of the sample corresponds almost exclusively to items in which both aforementioned principles are observed in combination with each other. Three cases are attested: APPROX=SPELL ("phonologically robust" items in which phonological approximation yields the same results as spelling pronunciation; FR: $18 \%$, DE: $12 \%$, CS: $14 \%$ ), APPROX+SPELL (phonologically hybrid loanwords; FR: 8\%, DE: $3 \%$, CS: $8 \%$ ) and APPROX/SPELL (parallel adaptation; FR: $14 \%$, DE: $13 \%$, CS: $4 \%$ ). Finally, a negligible number of German entries received the labels APPROX+Orig (3), APProx/Orig (1) and orig (7). For examples, see Table 1.

As can be seen from the three charts above, the system of loanword adaptation in French, German and Czech can be reduced to two primary principles, which act either alone, or in synergy. The comparative importance of these principles is summarised in Table 3 .

German tends to favour phonological approximation more than the other two languages, while spelling pronunciation is observed especially in French. Czech has an intermediate position. Hypothesis 3 is thus not refuted, but the difference seems to be gradual. The quantitative contrast between spelling pronunciation alone and all remaining principles taken together is statistically significant for any of the three language pairs $\left(\chi^{2}, \mathrm{p}<0.001\right)$. This also holds when we contrast spelling pronunciation alone or in combination against all remaining principles.

In Section 5, I pointed out that German dictionaries reflect tolerance towards foreign phonological forms to a variable degree. The DudenAussprachewörterbuch, used as the primary source, mostly recommends nativised forms (cf. the tiny number of items with a label containing "ORIG"), while the Duden - Deutsches Universalwörterbuch gives original pronunciation for a

TABLE 3 Comparative importance of adaptation principles

Adaptation principle(s)

phonological approximation alone

phonological approximation alone or in combination spelling pronunciation alone spelling pronunciation alone or in combination
Relative weight

$\mathrm{DE}>\mathrm{CS}>\mathrm{FR}$

$\mathrm{DE}>\mathrm{CS}>\mathrm{FR}$

$\mathrm{FR}>\mathrm{CS}>\mathrm{DE}$

$\mathrm{FR}>\mathrm{CS}>\mathrm{DE}$ 
substantial number of entries. After looking up the 690 German entries from the sample in this dictionary, I found out that $15 \%$ of them are not included, $51 \%$ are given with nativised pronunciation, $27 \%$ with original pronunciation, and $7 \%$ with both nativised and original pronunciation. These figures would change the chart in Figure 2 dramatically, increasing the segments ORIG and APPROX/ORIG, and reducing especially the segment APPROX (the proportion of entries affected by original pronunciation in German would be significantly higher than in the other two languages: $\left.\chi^{2}, p<0.001\right)$. The acceptance of original pronunciation in standard German dictionaries is variable and depends on the strategy of the authors. This situation contrasts sharply with the other two languages, for which standard dictionaries do not reflect original pronunciation. This observation, taken together with the data from Figure 2, allows us to confirm Hypothesis 4.

As for the secondary principles, I identified a limited number of entries in which the adaptation is influenced by analogy (FR: 16; DE: 22; CS: 42). In French and Czech, most of these cases are analogies with other words existing in the target language, which favour spelling pronunciation (FR: non-sense /nõsãs/; CS: reality show / realitr fou//). In German, this category mostly includes analogies with French pronunciation rules (Lunch /'lanf, 'lant/). Finally, a certain number of anomalous adaptations were identified (FR: 12; DE: 5; CS: 12). For examples, see Section 5 .

Phonological approximation was defined above as a conventional projection of the source phonological system onto the target system. In this section, I resume and comment on the rules of phonological approximation identified in the sample. Although a detailed analysis of the second major adaptation principle - spelling pronunciation - is also possible, it would be of little interest, because the rules that govern this type of phonological conversion are identical to those that apply to native words and can be found in most pronunciation guides and phonetics textbooks. The same holds for the remaining primary principle - original pronunciation - which does not involve adaptation.

\subsection{Monophthongs}

The system of monophthongs (Table 4) is reshaped according to the phonological contrasts available in each target language, with several mergers of perceptually adjacent phonemes and a few context-sensitive mappings. Unlike German and Czech, French has no vowel length contrast, which results in a particularly high number of phonemic fusions (12 English phonemes are 
TABLE 4 Approximation of monophthongs in the sample.
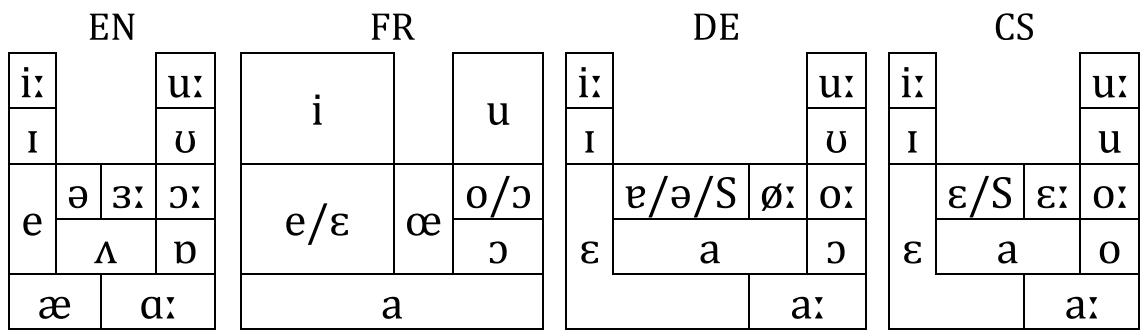

/S/ stands for a syllabic sonorant

mapped to eight French phonemes). Vowel lengthening in this language is contextual: all vowels are lengthened before word-final lengthening consonants (dealer [di'lœ:s]), and some vowels are lengthened in word-final closed syllables (hall [o:l]).

The adaptation of /i: $u: I \mho \quad 3: \Lambda \mathrm{b} /$ is straightforward in all three languages. Moreover, English /e/ is rendered in French either as $/ \varepsilon /$ (in all closed syllables and in many open syllables, e.g., week-end /wikend/, pressing /pьesin/) or as /e/ (in some open syllables, e.g., penalty /penalti/). However, since the contrast $/ \mathrm{e}-\varepsilon /$ in unstressed syllables is more or less neutralised in native words (Léon, 1992), it is reasonable to classify the choice /e- $\varepsilon /$ in Anglicisms as a case of free variation, with $/ \varepsilon /$ clearly prevailing (out of the 34 relevant entries, 29 contain $/ \varepsilon /$, three /e/ and two either $/ \varepsilon /$ or $/ \mathrm{e} /$ ). In stressed open syllables, French $/ \mathrm{e}-\varepsilon /$ do contrast, but this contrast is not relevant for Anglicisms, as no English /e/s occur in final open syllables.

English /æ/ merges with /a/ in French (this fusion is conditioned by a rather front articulation of French /a/), and with / $/$ / in German and Czech (gag: FR /gag/, DE /'gek/, CS /gek/). English / $\mathrm{s} /$ is mapped to French / / / (20 cases out of 23) or, marginally, /o/ (3 cases). About a half of the occurrences are in closed syllables before a restituted rhotic (13 cases), where the only phonotactically acceptable option is /ов/ (score/skor/, forcing/forsin/). Outside the rhotic context, both /o/ and /o/ are attested (walkman /wokman/, basketball /basketbol/). In German and Czech, /ə:/ yields the corresponding long vowel (DE: Walkman /'vo:kmen/, Score /'skồe/; CS: talkshow /to:kfou//, snowboard /snouborrt/).

In German and Czech, the long vowels /3: o: a:/ in rhotic contexts tend to be shortened in some words (DE: 26 cases out of 49, e.g., girl /'gø̋:el, 'gœrl/, Popcorn /'popkorn/, cartoon/kar'tu:n/;CS: 26 cases out of 41, e.g., return/ritern/, popcorn /popkorn/, bodyguard/bodiga:rt, bodigart/). Such vowel shortenings 
were labelled as spelling pronunciation, although the alternative solution accepting short vowels as regular counterparts of /3: $\mathrm{o}: \mathrm{a}$ / within the limits of phonological approximation - would have also been viable.

The treatment of $/ a /$ is context-sensitive and fairly complex. In French, there is a / / / phoneme, but its distribution is limited to unstressed syllables. In most words in the sample ( 78 cases out of 79 , excluding entries with spelling pronunciation), /a/ occurs in a word-final syllable (fashion, leader, poster), which receives stress when the word is adapted to French. Therefore, /ə/ is not an acceptable candidate. Instead, French uses /œ/, which is acoustically close to $/ \partial /$ (all the more so because French $/ \partial /$ is slightly rounded). In potentially rhotic contexts, which prevail in the sample (61 cases), the rhotic consonant is systematically restituted. This combination of phonotactic constraints then leads to the projection $/ \mathrm{\partial}^{\mathrm{r}} />/$ /ев/ (leader /lidœe /, thriller / tвilœв/). A potential /ə/ before a sonorant (17 cases) is adapted to [œ], or, more rarely, omitted or swapped with the sonorant (Scrabble /skьabœl, skьabl, skьablə/).

In English, /a/ elision triggers the sonorant's syllabicity; this is never the case in French, which does not tolerate syllabic consonants. Only in one word is unstressed /ə/ rendered as /ə/ (barbecue /barbəkju, basbəky/). German has an /ə/ phoneme, but substitutes English /a/ in rhotic contexts (137 cases out of 195, excluding entries with spelling pronunciation or original pronunciation) with a slightly more open vowel /e/ (Dealer /'dille/, Paperback /'pe:pebek/), as it is the rule in native words. A potential /a/ before a sonorant (39 cases) is omitted, and the sonorant becomes syllabic (Scrabble /'skrebl/, Slogan /'slo:gn/). Only in two entries with the sequence /m(ə)n/ (Backgammon and Common Sense) does the dictionary keep an /ə/. In other contexts (19 cases), /ə/ is maintained (e.g., Catering/'ke:tərry/). In Czech, there is no /a/ phoneme. A potentially rhotic $/ \mathrm{o}^{\mathrm{r}} /$ (83 cases out of 123 , excluding entries with spelling pronunciation) is adapted either as a syllabic / $\mathrm{r} /$ (svetr /svetr/), or as / $/ \mathrm{r} /$ (dispečer / dispetfer/). For some entries, both variants are given (cracker $>k r e k r /$ $k r e k e r / k r \varepsilon k r, k r \varepsilon k \varepsilon r /)$. The choice of the variant seems to be fortuitous, with the former being more frequent than the latter (/r/: 55 entries; / $/ \mathrm{r} /: 23$ entries; $/ \mathrm{r} /$ or $/ \varepsilon r /: 5$ entries). A potential /ə/ before a sonorant ( 28 cases) is omitted (fashion $/ \mathrm{f} \varepsilon \mathrm{fn} /$, scrabble /skrebl/), except for the sequence $/ \mathrm{m}(ə) \mathrm{n} /$, where it is adapted to / $/$ / (gentleman / dzentlmen/). In all other contexts (12 cases), /ə/ is

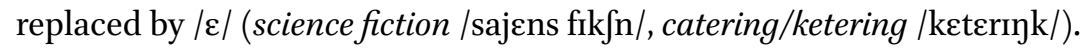

\subsection{Diphthongs}

The phonological approximation of diphthongs is displayed in Table 5. The treatment of closing (i.e., non-rhotic) diphthongs can be generalised by means of a set of three rules of preference: 
1. diphthong if available, else

2. sequence of vowel and semi-vowel if phonotactically acceptable, else

3. monophthong.

TABLE 5 Approximation of diphthongs in the sample.

\begin{tabular}{|c|c|c|c|}
\hline EN & $\mathbf{F R}$ & DE & CS \\
\hline eI ગI aI & $\varepsilon(\supset \mathrm{j}) \mathrm{aj}$ & e: วy ầ & عj əj aj \\
\hline әઇ аひ & o aw & o: âu & oû au \\
\hline Іә еә ઇә & (іь) $(\varepsilon \mathbf{в})-$ & $(\mathrm{irr} / \widehat{\mathrm{I} e} \mathrm{e})(\overline{\varepsilon r} / \widehat{\varepsilon \backsim e})-$ & $(\mathrm{ir} / \mathrm{irr})(\varepsilon r / \varepsilon: r)-$ \\
\hline
\end{tabular}

In French, which is a language without diphthongs, constraint (1) is skipped. All diphthongs but two are thus rendered as $\mathrm{V}+\mathrm{j} /$ or $/ \mathrm{w} /$ sequences (boy-scout /bojskut/, copyright /kopiвajt/, black-out/blakawt/). The diphthongs /er әə/are monophthongised into / $\varepsilon$ o/ (fair play /fєьрle/, cashflow /kafflo/). In the latter of the two, this change is inevitable since the hypothetical counterparts */ow, ow, ow/ are phonotactically impossible. The sequence / $/ \mathrm{j} /$ occurs in native words (sommeil, je payerai), but is avoided as a counterpart of /eI/, possibly for the sake of symmetry, since /ei/ and /ə凶/ are the two English diphthongs with the smallest articulatory trajectory, which also undergo monophthongisation in some accents of English, including American (Ladefoged, 1999). In German, constraint (2) is skipped because $\mathrm{V}+$ semivowel sequences are not tolerated. All diphthongs but two are mapped to similar German diphthongs (boiler /'boyle/, Halftime /'ha:ftaîm/, Scout /'skaut/). The diphthongs /eı əə/ - the same as in French - are monophthongised and additionally lengthened (fair play /'f̌̂:e'ple:/, cashflow /'keflo:/). In Czech, constraint (3) is skipped. The $\mho$-diphthongs are mapped to available equivalents (landrover /lendrouvr/, soundtrack /saunttrek/), and the $\mathrm{I}$-diphthongs are replaced with $\mathrm{V}+/ \mathrm{j} /$ sequences (paperback /pejprbek/, spoiler/spojler/, ragtime/rektajm/).

The centering (i.e., potentially rhotic) diphthongs /ı еə ๘ə/ have a very limited frequency in the sample, and one of them $(/) /)$ is missing altogether. Despite these fragmentary data, we can generally describe the approximation of these diphthongs as a monophthongisation with r-restitution (FR:

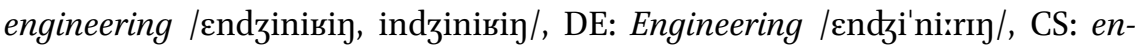
gineering /endzmirrm $\mathrm{k} /$ ). In German, the rhotic takes the vocalised form /e/ syllable-finally (Pier /'pî̀/). Vowels are always lengthened in German and sometimes in Czech (7 cases out of 10). 


\subsection{Consonants}

Table 6 shows the rules of phonological approximation for English consonants. The r-restitution in French and Czech could be interpreted as a case of spelling pronunciation. However, I decided to classify it as phonological approximation for two reasons: first, the $/ \mathrm{r} /$ is pronounced in rhotic accents of English, and second, an underlying / $\mathrm{r} /$ may appear in surface even in non-rhotic accents (star - starring, for - for instance). In Czech, [n] is an allophone of /n/ occurring only before $/ \mathrm{k}, \mathrm{g} /$. This constraint is active also in Anglicisms, where a velar plosive is always restituted if it is not present in the source phonological form. Its voicing is determined by spelling and the rule of word-final devoicing (drink/drınk/, bowling /boûlınk/, singl/single /singl/).

TABLE 6 Approximation of consonants in the sample.

\begin{tabular}{|c|c|c|c|}
\hline $\mathbf{E N}$ & $\mathbf{F R}$ & DE & CS \\
\hline $\begin{array}{l}\text { pbtdkgtds } \\
m n f v z \int r j l\end{array}$ & \multicolumn{3}{|c|}{ no change except for cases below } \\
\hline $\begin{array}{l}\text { Word-final } \\
\text { obstruents }\end{array}$ & no change & $\begin{array}{l}\text { devoicing } \\
\text { gag /'gek/ }\end{array}$ & $\begin{array}{l}\text { devoicing } \\
\text { gag /gek/ }\end{array}$ \\
\hline $\begin{array}{l}\text { Syllable-final } \\
\text { obstruents }\end{array}$ & no change & $\begin{array}{l}\text { devoicing } \\
\text { Badminton } \\
\text { /'betmintn/ }\end{array}$ & no change \\
\hline $\begin{array}{l}\text { Potential } \\
\text { syllable-final } \\
\text { /r/ }\end{array}$ & $\begin{array}{l}\text { restitution } \\
\text { shaker } \\
\text { / } \varepsilon \text { kкœь/ }\end{array}$ & no restitution & $\begin{array}{l}\text { restitution } \\
\text { šejkr / } \int \varepsilon j k r /\end{array}$ \\
\hline$\theta$ ð & $(\mathrm{t})-$ & $(\theta)(ð)$ & $(\mathrm{t})(\mathrm{z})$ \\
\hline s & no change & $\begin{array}{l}\text { word-initial voicing } \\
\text { before vowel } \\
\text { Single /'zinl/ }\end{array}$ & no change \\
\hline $\mathrm{h}$ & $\begin{array}{l}\text { elision } \\
\text { hold-up } \\
\text { /oldœp/ }\end{array}$ & no change & $\begin{array}{l}\text { h } \\
\text { hit / hit/ }\end{array}$ \\
\hline$\eta$ & no change & no change & $\begin{array}{l}\text { yk, yg } \\
\text { holding / houldı̂k/ }\end{array}$ \\
\hline w & no change & $\begin{array}{l}\text { v } \\
\text { Sandwich /'zentvitf/ }\end{array}$ & $\begin{array}{l}\mathrm{v} \\
\text { sendvič /sendvitf/ }\end{array}$ \\
\hline
\end{tabular}

The $/ 3 /$ phoneme is not attested, and the phonemes $/ \partial \theta /$ are represented by a very small number of entries. Different realisations of $/ \mathrm{r} /$ are not taken into consideration 


\subsection{Prosody}

As far as word stress is concerned, French and Czech - fixed-stress languages normalise its position (FR: pull-over /pylı'veь, pulo'vœь/, CS: pulovr/'pulovr/), while German - a free-stress language - maintains its original position (DE: Pullover/po(l)'lo:ve/). There are some exceptions to this rule (7 cases, e.g., discount /'dıskaunt/ > DE: Discount /dıs'kâunt/).

\subsection{British vs. American English}

All the processes of phonological approximation that have been described above are considered from the perspective of standard British pronunciation. Additionally, I checked whether some of them would be better described with American English pronunciation forms, given the undeniable cultural role of this variety in today's world. I considered the following six systematic variations (Wells, 1982):

1. Rhoticity: As has been said above, the r-restitution in French and Czech can be explained as a joint influence of spelling and the awareness of rhotic accents of English.

2. /a:/ vs. /æ/ as in casting /'ka:stın/ vs. /'kæstın/: No case of AmericanEnglish-based adaptation was recorded in German or Czech. In French, this variation is irrelevant, as both phonemes lead to /a/.

3. /v/ vs. /a:/ as in boxer /'boksə/ vs. /'barksə/: No case of US-Englishbased adaptation was recorded in any of the three languages.

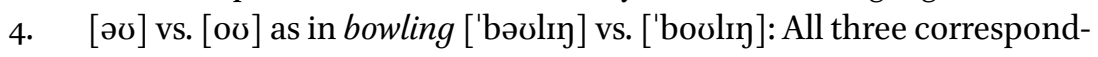
ing forms (FR: /o/, DE: /o:/, CS: /ou/) are closer to the American variant.

5. /j/ deletion as in steward /'stjurəd/ vs. /'sturəud/: This variation is only documented by two items in German. The British model prevails.

6. /t/ flapping and voicing as in duty ['djurti] vs. ['durti]: No case of American-English-based adaptation was recorded in any of the three languages.

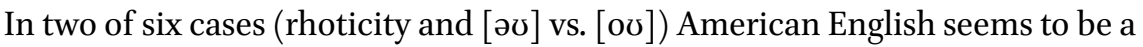
better candidate for the source phonological form. However, rhoticity and the o-colouring of / /əv/ are also present in spelling, correspond to historically older stages of language evolution (Minkova, 2014), and are shared by other accents of English. For these reasons, it would probably be an oversimplification to ascribe these preferences to the sole influence of American English. 


\subsection{Permeability/Resistance in Phonological Approximation}

In Figure 1, I proposed a scale that demonstrates the degree of phonological permeability/resistance for each of the three primary adaptation principles. Phonological approximation, positioned in the centre of this scale, can itself be seen as a continuum between more or less permeable/resistant, according to the resemblance between the source system and its projection in the target language. When comparing the number of differences in each of the four domains under examination (monophthongs, diphthongs, consonants, stress), we arrive at the following simplified diagram (Figure 3). With regard to the amount of manipulation needed in phonological approximation, German seems to be slightly more permeable than Czech and significantly more permeable than French. Hypothesis 1 therefore holds only with respect to the relationship between German and French.

$\begin{array}{lcc} & \begin{array}{c}\text { Less resistant } \\ \text { More permeable }\end{array} & \begin{array}{c}\text { More resistant } \\ \text { Less permeable }\end{array} \\ \text { Monophthongs } & \text { DE, CS } & \text { FR } \\ \text { Diphthongs } & \text { DE, CS } & \text { FR } \\ \text { Consonants } & & \text { FR, DE, CS } \\ \text { Stress } & \text { DE } & \text { FR, CS }\end{array}$

FIGURE 3 Permeability/resistance in phonological approximation

The question of phonological permeability/resistance was decomposed into four hypotheses of which three were confirmed (Hypotheses 2, 3 and 4) and one was not (Hypothesis 1):

1. With respect to the straightforwardness of phonological approximation, German, though closely related to English, does not differ from Czech significantly. The observed degree of phonological manipulation in German is higher than in French but roughly comparable to the degree of phonological manipulation in Czech (see Figure 3).

2. The principle of phonological approximation prevails in all three languages and can be considered the default principle of loanword adaptation in each of them (see Figure 2).

3. Spelling pronunciation is especially prevalent in French, but the difference is more gradual than categorial $(\mathrm{DE}<\mathrm{CS}<\mathrm{FR}$; see Figure 2). 
4. German is more tolerant towards original pronunciation than the other two languages (see Figure 2 and following text).

The partial conclusions made above are summarised in Figure 4.

The degree of permeability/resistance in phonological approximation is determined by the disposition of each language to accommodate foreign phonological input. Unsurprisingly, this disposition is particularly high in German, a language closely related to English. Some typological properties of Czech (namely vowel length contrast and syllabic consonants) allow for a rather smooth phonological projection as well. The projection onto the French phonemic system, on the other hand, is accompanied by a number of phonemic fusions and constraint-based modifications. Consequently, the phonological structure of many borrowings moves away from both their original English form and their spelling. It is perhaps for this reason that French favours spelling pronunciation, which is a way to ensure better recognisability.

The other conclusions can only be explained by system-external factors. The overall openness of a language towards Anglicisms (both diachronic and synchronic) increases the size of this lexical stratum, which may help stabilise the system of phonological approximation. Regular phonological approximation is also stimulated by the knowledge of English in the population. Finally, language institutions and dictionaries, whose position may be reflected by the media and the school system, also impact on pronunciation practice. Unlike Czech or French, German is particularly permeable to direct phonological transfer from English: this phenomenon has a social basis, but is probably enhanced by the proximity of both phonological systems.

The ranking of global phonological permeability with respect to Anglicisms can thus be defined as DE > CS >> FR, with Czech being closer to German than to French.

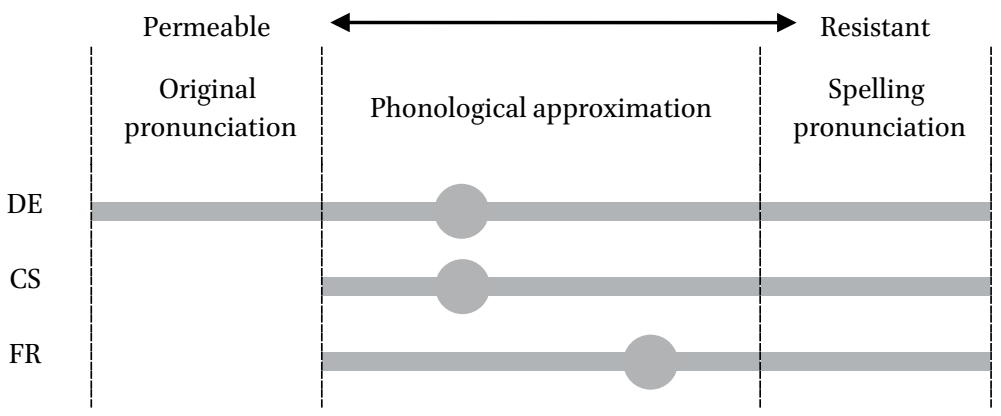

FIGURE 4 Overall typological scheme of adaptation processes.

The thick grey line delimits the part of the adaptation scale that is used by the language in question. Grey dots denote the dominant area within phonological approximation 
Finally, it should be noted once again that the validity of the analysis is limited by the methodology used: the phonological forms are dictionary-based and do not therefore reflect the full phonological variability of the studied loanwords.

\section{Acknowledgement}

This research was supported by the GAČR 16-06012S grant.

\section{References}

Aitokhuehi, Emmanuel. 1996. L'intégration graphique et phonique de l'anglicisme. Initial (e)s 15: 12-24.

Bičan, Aleš, Tomáš Duběda, Martin Havlík, and Veronika Štěpánová. 2020. Fonologie českých anglicismů. Praha: Lidové noviny.

Busse, Ulrich. 2005. Beobachtungen und Überlegungen zur Aussprache englischer Wörter im Deutschen und ihrer Repräsentation in ausgewählten Wörterbüchern. In Henrik Gottlieb (ed.), Symposium on Lexicography XI, 159-183. Tübingen: Max Niemeyer.

Calabrese, Andrea. 2009. Perception, production and acoustic inputs in loanword phonology. In Andrea Calabrese, and W. Leo Wetzels (eds.), Loan Phonology, 59-114. Amsterdam - Philadelphia: John Benjamins.

Calabrese, Andrea, and W. Leo Wetzels (eds). 20og. Loan Phonology. Amsterdam and Philadelphia: John Benjamins.

Dabo-Denegri, Ljuba. 1991. Phonological Adaptation of Anglicisms in French. In Rudolf Filipović (ed.), The English Element in European Languages, Vol. 3, 59-79. Zagreb: University of Zagreb.

Dankovičová, Jana. Czech. In Handbook of the IPA, 70-73. Cambridge: Cambridge University Press.

Duběda, Tomáš, Martin Havlík, Lucie Jílková, and Veronika Štěpánová. 2014. Loanwords and Foreign Proper Names in Czech: A Phonologist's View. In Joseph Emonds, and Markéta Janebová (eds.), Language Structure and Language Use. Proceedings of the Olomouc Linguistics Colloquium 2013, 313-321. Olomouc: Palacký University.

Duběda, Tomáš. 2016a. Empirické mapování výslovnostního úzu u cizích slov. Slovo a slovesnost 77: 123-142.

Duběda, Tomáš. 2016b. L'invasivité phonologique dans le traitement des anglicismes : une étude quantitative de trois langues. JEP-TALN-RECITAL 2016. 401-409.

Duden. Deutsches Universalwörterbuch. 2007. Mannheim: Bibliographisches Institut AG. 
Escudero, Paola and Karin Wanrooij. 2010. The effect of Li orthography on non-native vowel perception. Language and Speech 53: 343-365.

Filipović, Rudolf (ed.). 1982. The English Element in European Languages, Vol. 2. Zagreb: University of Zagreb.

Fink, Hermann. 1980. Zur Aussprache von Angloamerikanischem im Deutschen. In Wolfgang Viereck (ed.), Studien zum Einflußder englischen Sprache auf das Deutsche, 109-183. Tübingen: Narr.

Fougeron, Cécile and Caroline L. Smith. 1999. French. In Handbook of the IPA, 78-81. Cambridge: Cambridge University Press.

Friesner, Michael L. 2009. The adaptation of Romanian loanwords from Turkish and French. In Andrea Calabrese and W. Leo Wetzels (eds.), Loan Phonology, 115-130. Amsterdam and Philadelphia: John Benjamins.

Görlach, Manfred (ed.). 2001. A Dictionary of European Anglicisms. A Usage Dictionary of Anglicisms in Sixteen European Languages. Oxford: Oxford University Press.

Görlach, Manfred (ed.). 2002. An Annotated Bibliography of European Anglicisms. Oxford: Oxford University Press.

Le grand Larousse illustré 2017. 2017. Paris: Larousse.

Hůrková, Jiřrina. 1995. Česká výslovnostní norma. Prague: Scientia.

Jones, Daniel, Peter Roach, Jane Setter, and John Esling. 2011. Cambridge English Pronouncing Dictionary. $18^{\text {th }}$ edition. Electronic version. Cambridge: Cambridge University Press.

Kang, Yoonjung. 2011. Loanword Phonology. In Marc van Oostendorp, Colin J. Ewen, Elizabeth V. Hume, and Keren Rice (eds.), The Blackwell Companion to Phonology, 2258-2282. Malden, Oxford and Victoria: Blackwell.

Kohler, Klaus. 1999. German. In Handbook of the IPA, 86-89. Cambridge: Cambridge University Press.

Kučera, Jiří and Jiří Zeman. 1998. Výslovnost a skloňování cizích osobních jmen v češtině. Anglická osobníjména. Hradec Králové: Gaudeamus.

Ladefoged, Peter. 1999. American English. In Handbook of the International Phonetic Association, 41-44. Cambridge: Cambridge University Press.

Lange, Friderike. 2015. Standardaussprache englischer Namen im Deutschen. Berlin: Frank and Timme.

Léon, Pierre R. 1992. Phonétisme et prononciations du français. Paris: Nathan.

Maddieson, Ian. 1984. Patterns of sounds. Cambridge: Cambridge University Press.

Mangold, Max. 2005. Duden. Das Aussprachewörterbuch. Mannheim and Zürich: Dudenverlag.

Minkova, Donka. 2014. A Historical Phonology of English. Edinburgh: Edinburgh University Press.

Molęda, Jacek. 2011. A Comparative Study of Phonological Adaptations of Anglicisms in Czech and in Polish since the 199os. Racibórz: Państwowa Wyższa Szkoła Zawodowa v Raciborzu. 
Muhvić-Dimanovski, Vesna. 1982. The English Element in German. The Phonological and Morphological Adaptation. In Rudolf Filipović (ed.), The English Element in European Languages, Vol. 2, 213-243. Zagreb: University of Zagreb.

Nový akademický slovník cizích slov. 2005. Prague: Academia.

Léon, Pierre. 2011. Phonétisme et prononciations du français. Paris: Armand Colin.

Le Petit Robert de la langue française. 2012. Electronic edition. Paris: Dictionnaires Le Robert.

Retman, Roman. 1978. L'adaptation phonétique des emprunts à l'anglais en français. La Linguistique 14(1) 111-124.

Romportl, Milan (ed.). 1978. Výslovnost spisovné češtiny. Prague: Academia.

Seridj, Fouad. 2013. De l'intégration des emprunts français lais: cas des anglicismes informatiques dans les revues en ligne. Synergies Algérie 19: 197-213.

Slovník současné češtiny. 2011. Brno: Lingea.

Slovník spisovné češtiny pro školu a veřejnost. 200o. Prague: Academia.

Smith, Jennifer L. 2006. Loan phonology is not all perception: Evidence from Japanese loan doublets. In Timothy J. Vance, and Kimberly A. Jones (eds.), Japanese/Korean Linguistics 14, 63-74. Stanford: Stanford University.

Štěpánová, Veronika. 2013. Pojetí výslovnosti v českých výkladových slovnících (výzva $\mathrm{k}$ diskusi). Slovo a slovesnost 74(4) 279-297.

Tranel, Bernard. 1987. The Sounds of French. An Introduction. Cambridge: Cambridge University Press.

Trescases, Pierre. 1987. Phonétisation automatique du français et aménagement phonético-graphique des emprunts à l'anglais. Meta : journal des traducteurs 32(3) 230-239.

Vance, Timothy J. 2008. The Sounds of Japanese. Cambridge: Cambridge University Press.

Warnant, Léon. 1987. Dictionnaire de la prononciation française dans sa norme actuelle. Paris - Gembloux: Duculot.

Walter, Henriette. 1976. La dynamique des phonèmes dans le lexique français contemporain. Paris: France Expansion.

Walter, Henriette. 1983. La nasale vélaire /y/. Un phonème du français ? Langue Française 6o: 14-29.

Wells, J. C. 1982. Accents of English 1. An Introduction. Cambridge: Cambridge University Press. 